\title{
YOUNG PEOPLE'S PREFERENCES FOR ROMANIAN AGRO ALIMENTARY GOODS
}

\author{
Laura Cătălina Țimiraş \\ "Vasile Alecsandri" University of Bacau, \\ timiras.laura@ub.ro
}

\begin{abstract}
Based on the results of a research undertaken among young people (18-30 years), students of the Faculty of Economic Sciences of the Vasile Alecsandri University of Bacau, this paper reveals their preference for local or foreign brands (on the Romanian market) for various categories of food products. It is also highlighted their views on certain essential evaluation criteria for food products (sanogenetic potential, value for money, appearance, taste, availability within commercial network, promotions, image), comparing Romanian and foreign products. The survey shows that the preference for Romanian brands applies particularly to: eggs, bakery products, grain mill, milk and dairy products, fruits and vegetables, meat and meat products (over 50\% of the investigated people). A large proportion of young people believes that Romanian products are tastier and healthier than foreign ones, the better image enjoyed by foreign brands being a result of the promotion and packaging of products and not the quality of product; they also believe that Romanian brands are insufficiently promoted nationally, perceiving offer of imported products as being broader than the local one. The research was conducted on a sample of 100 students selected by the group sampling scheme and has an exploratory role for the community of 18-30 years people in Romania, offering, for it, only an indicative perspective on the raised issues.
\end{abstract}

\section{Keywords}

agro alimentary goods; preferences; Romanian brand; foreign brand

\section{JEL Classification}

M31

Food purchase and consumption behavior of the population is largely determined by cultural baggage acquired in the family. Besides transmitting eating habits from generation to generation, within the behavior is manifested their transformation over time resulting from: cultural transfers from different groups / communities (groups of affiliation - other than family), including other cultures; marketing activities of agents operating in the market's etc. The specific cultural transfers regarding dietary habits of other cultures is manifested more visible in the Romanian market, young people being generally more receptive to the acquisition and therefore, to modification / waiver of some habits belonging to indigenous culture.

The absence or low expression of traditionalism can manifest itself not only by borrowing dietary habits which are not specific to Romanian culture but can also contribute to preference for foreign food products to the detriment of indigenous ones. Of course, the orientation to other than domestic products cannot be attributed solely to the lack of traditionalism, being necessary to considering other triggers (the unfavorable experiment with certain domestic products, the increased confidence in the products produced in other countries, etc.). 
This paper presents results of a research directly carried out among the segment of young people (considered to be the less traditionalist) with reference to their preference to local brands versus foreign ones in the Romanian market, by categories of food products, and also highlights their opinion regarding Romanian food products compared to foreign ones in terms of certain essential evaluation criteria.

\section{Research methodology}

The research was conducted among students of undergraduate studies with frequency of the Faculty of Economic Sciences of the Vasile Alecsandri University of Bacau, results being practically representative exclusively for this collectivity, for a guaranteed probability of $95 \%$ and an error of $2,17 \%$

The research method was survey using self-registration process of completing the questionnaires.

The research was conducted in the month of April 2016.

The studied sample was 100 respondents aged 18-30.

Group sampling has been used, with randomly selection of four teams of students from a number nine who were subject to evaluation.

\section{Research limits}

As stated previously, results of research are only representative for the collectivity formed by students of the Faculty of Economic Sciences of the Vasile Alecsandri University of Bacau. Although the statistical information cannot expand to the community made up of young people 18-30 years of Bacau and Romania, they have provided a guideline on youth preference for local brands for different categories of studied food products.

\section{The research results regarding the young Romanian preference for food products}

Young people preference for origin of the brand - domestic or foreign - has been studied for a total of 22 product categories. Young subjects were asked to indicate whether they prefer Romanian brands, foreign brands, or both two categories and if they know if favorite brands are Romanian or foreign, or have preferences in this regard, for each of the 22 categories of food products.

The results shown in the Table 1 confirm that the products for which young people prefer Romanian brands are mainly the usual ones, intended for current consumption which have a high degree of perishability and / or requiring further processing to be consumed: eggs and bakery products, milling, dairy, vegetables and fruits, meat and processed meat and ready meals (excluding fish); $50 \%$ of young people preferring Romanian brands for these product categories.

A significant proportion of the respondents (40\%) said they would rather equally prefer Romanian and foreign brands, especially in the case of: confectionery, nuts and seeds, soft drinks, chocolate, chips and snacks, alcoholic beverages, cereals (ready-toserve), margarine.

Comparing the number of those who indicated that they prefer Romanian brands with those who prefer foreign brands we found that is especially the case of festive products and / or products that do not need / require minimal processing (coffee, chocolate, crisps and snacks, tea, confectionery, alcoholic beverages and soft drinks, nuts and seeds, cereals (ready-to-serve) are preferred in greater extent foreign brands, although in no case, the share of those who said they prefer that category of brands has not exceeded 50\%. Basically, except coffee, for all other product categories the 
percentage of those who said they prefer equally Romanian and foreign brands exceeded the percentage of those who said they prefer foreign brands.

However, overall, we can say that Romanian brands of food products are preferred to a greater extent than foreign brands, for a total of 13 product categories, young people saying they prefer Romanian brands, and for a number of 9 categories foreign ones. Moreover, the gap between the percentage of those who prefer Romanian brands and of those who prefer foreign brands is much higher in case of products for which local brands are favorite.

We identifies for certain categories of products (canned meat and vegetables, coffee, alcoholic beverages, fish) a relatively high share (over 20\%) of those who have not expressed a preference or didn't know if favorite brands are Romanian or foreign.

Table no. 1. Distribution of respondents according to the preference for the origin of the brand of food products - domestic or foreign - by product category (\% of total investigated sample)

\begin{tabular}{|l|c|c|c|c|c|}
\hline Product category & $\begin{array}{c}\text { I prefer } \\
\text { especially } \\
\text { Romanian } \\
\text { brands }\end{array}$ & $\begin{array}{c}\text { I prefer } \\
\text { especially } \\
\text { foreign } \\
\text { brands }\end{array}$ & $\begin{array}{c}\text { I prefer } \\
\text { equally } \\
\text { Romanian } \\
\text { and foreign } \\
\text { brands }\end{array}$ & $\begin{array}{c}\text { I do not know } \\
\text { if favorite } \\
\text { brand / brands } \\
\text { are Romanian } \\
\text { or foreign }\end{array}$ & $\begin{array}{c}\text { Do not } \\
\text { know / No } \\
\text { preference }\end{array}$ \\
\hline Eggs & 77 & 2 & 14 & 2 & 5 \\
\hline Bakery products & 67 & 5 & 22 & 1 & 5 \\
\hline Milling products & 65 & 4 & 19 & 2 & 10 \\
\hline $\begin{array}{l}\text { Milk and dairy } \\
\text { products }\end{array}$ & 55 & 5 & 30 & 2 & 8 \\
\hline Vegetables and fruits & 53 & 6 & 37 & 2 & 2 \\
\hline $\begin{array}{l}\text { Meat and precooked } \\
\text { meat (except fish) }\end{array}$ & 52 & 5 & 32 & 2 & 9 \\
\hline Oil & 49 & 4 & 33 & 5 & 9 \\
\hline Sugar & 44 & 6 & 37 & 3 & 10 \\
\hline $\begin{array}{l}\text { Canned meat } \\
\text { (including pate) }\end{array}$ & 39 & 13 & 22 & 3 & 23 \\
\hline Margarine & 39 & 3 & 42 & 3 & 13 \\
\hline Fish and eggs & 37 & 12 & 30 & 6 & 15 \\
\hline Canned vegetables & 36 & 8 & 30 & 3 & 23 \\
\hline Pasta & 33 & 22 & 34 & - & 11 \\
\hline Tea & 21 & 27 & 35 & 4 & 13 \\
\hline $\begin{array}{l}\text { Cereals (ready-to- } \\
\text { serve) }\end{array}$ & 20 & 22 & 43 & 2 & 13 \\
\hline Nuts and seeds & 16 & 22 & 50 & 6 & 6 \\
\hline $\begin{array}{l}\text { Sugar confectionery } \\
\text { (excluding } \\
\text { chocolate) }\end{array}$ & 13 & 26 & 56 & 3 & 2 \\
\hline Alcoholic beverages & 13 & 24 & 43 & 2 & 12 \\
\hline Soft drinks & 12 & 27 & 47 & 2 & 12 \\
\hline Chocolate & 10 & 40 & 46 & 3 & 1 \\
\hline Chips and snacks & 8 & 30 & 46 & 5 & 20 \\
\hline Coffee & 5 & 49 & 24 & & 2 \\
\hline
\end{tabular}

Source: own research 
Conducted research aimed to evaluate the opinions of young people on the Romanian food products compared to foreign ones, in terms of the essential criteria for the evaluation of these products: the sanogenetic potential, value for money, appearance, taste, availability in commercial network promotions, the image. Thus, young people were given a series of statements, they expressing their consent using a scale with 3 levels, the distribution from this point of view being presented in Table. 2.

Based on the presented distribution and mean scores value (to determine the average score of each level on the scale of assessments, it was awarded scores, respectively: 1 - Agreement 0 - Partial Agreement, -1 - Disagreement), we can say the following:

- Romanian food products are generally considered healthier than those imported, 39\% of respondents agreeing with the statement "In general, Romanian food products are healthier than those imported.", while only $2 \%$ showed their disagreement.

- Referring to the value for money characteristic, it is not a major differences between those who agree and those who disagree with the statement "In general, Romanian food products are better in terms of value for money compared to the imported ones.";

- Similarly, in case of attractiveness, there is a relatively similar percentage between those believing that Romanian products are more attractive and those believing imported ones are more attractive;

- Romanian food products are considered tastier than imported ones, over 50\% of the investigated persons agreeing with the statement "Romanian food products are often tastier than imported ones", while only $9 \%$ showed their disagreement;

- The biggest differences between those who agree and those who disagree are recorded for the statements: "Romanian food products are not sufficiently promoted nationwide" and "In the commercial network, the supply of imported products is often broader than Romanian one ", $69 \%$ and $62 \%$ of respondents indicating their agreement in relation to them, compared to $3 \%$ and $7 \%$ disapproval.

- "Better image enjoyed by foreign brands is generated from the promotion and packaging of products and not the quality of the basic product." was also a statement with a large number of supporters (42\%), while $13 \%$ did not agree with statement.

The points made above are confirmed by the mean scores, their values stating that in average Romanian products compared to imported ones are healthier, tastier, insufficiently promoted, and less abundant, the better image of foreign products being generated by the promotion and packaging and not by the quality of the basic product.

Table no. 2. Distribution of respondents according to opinion regarding a series of statements with respect to domestic and foreign food products and mean score for each statement

\begin{tabular}{|l|c|c|c|c|c|}
\hline \multicolumn{1}{|c|}{ Statement } & $\begin{array}{c}\text { Agree } \\
(1)\end{array}$ & $\begin{array}{c}\text { Partial } \\
\text { agree } \\
(0)\end{array}$ & $\begin{array}{c}\text { Disagree } \\
(-1)\end{array}$ & $\begin{array}{c}\text { Do not } \\
\text { know / } \\
\text { Cannot } \\
\text { say }\end{array}$ & $\begin{array}{c}\text { Mean } \\
\text { score* }\end{array}$ \\
\hline $\begin{array}{l}\text { In general, Romanian food products are } \\
\text { healthier than those imported. }\end{array}$ & 39 & 49 & 2 & 10 & 0.41 \\
\hline $\begin{array}{l}\text { In general, Romanian food products are } \\
\text { better value for money compared to the } \\
\text { imported ones. }\end{array}$ & 24 & 40 & 18 & 18 & 0.07 \\
\hline
\end{tabular}




\begin{tabular}{|l|c|c|c|c|c|}
$\begin{array}{l}\text { Often, the Romanian food products are } \\
\text { not as attractive (aspect) than the } \\
\text { imported ones. }\end{array}$ & 33 & 35 & 28 & 4 & 0.05 \\
\hline $\begin{array}{l}\text { Often, the Romanian food products are } \\
\text { tastier than imported ones. }\end{array}$ & 53 & 36 & 9 & 2 & 0.45 \\
\hline $\begin{array}{l}\text { Romanian food products are not } \\
\text { sufficiently promoted nationally. }\end{array}$ & 69 & 25 & 3 & 3 & 0.68 \\
\hline $\begin{array}{l}\text { In commercial network, the supply of } \\
\text { imported products is often broader than } \\
\text { the specific Romanian food products. }\end{array}$ & 62 & 23 & 7 & 8 & 0.60 \\
\hline $\begin{array}{l}\text { Better image enjoyed by foreign brands } \\
\text { is generated from the promotion and } \\
\text { packaging of products, not by basic } \\
\text { product quality. }\end{array}$ & 42 & 39 & 13 & 6 & 0.31 \\
\hline
\end{tabular}

* Scores determined on a scale from 1 to -1. In determining the average score was not taken into account the number of those who did not indicate one of the three levels listed.

Source: own research

Between shown preference of young toward Romanian brands and appreciation of some of the aspects evaluated by the statements presented in Table. 2 are certain associations. Thus, we studied the existence of differences in the categories of respondents according to various statements agreement and the categories of food products where Romanian brands are preferred, using contingency tables and $\chi^{2}$ test. Significant differences for a probability of results guarantee of $90 \%$ and respectively 95\% were found between preference for Romanian brands of food products and agreement to the following statements:

- $\quad$ "In general, Romanian food products are healthier than imported ones";

- $\quad$ "Romanian food products are often tastier than imported ones."

Thus, as was natural it was found that the one who believes Romanian food products healthier and tastier prefer Romanian brands to a larger number of product categories. Distributions of respondent preference for Romanian brands and agrees with the above statements and the corresponding $\chi^{2}$ values are calculated and tabulated in Tables No. 2, 3, 4 and 5.

Table no. 3. Distribution of respondents by agreeing to the statement "In general, Romanian food products are healthier than imported ones" and the product categories where they prefer local brands

\begin{tabular}{|c|c|c|c|c|c|c|}
\hline \multirow{2}{*}{$\begin{array}{c}\text { Number of } \\
\text { product } \\
\text { categories } \\
\text { where they } \\
\text { prefer local } \\
\text { brands }\end{array}$} & \multicolumn{3}{|c|}{ Number of respondents } & \multicolumn{3}{|c|}{$\%$ in total subgroup } \\
\hline & Agreement & $\begin{array}{c}\text { Partial } \\
\text { agreement }\end{array}$ & Disagreement & Agreement & $\begin{array}{c}\text { Partial } \\
\text { agreement }\end{array}$ & Disagreement \\
\hline $0-5$ & 12 & 14 & 2 & 30.8 & 28.6 & 100.0 \\
\hline $6-11$ & 15 & 28 & & 38.5 & 57.1 & 0.0 \\
\hline $12-17$ & 9 & 7 & & 23.1 & 14.3 & 0.0 \\
\hline $18-22$ & 3 & & & 7.7 & 0.0 & 0.0 \\
\hline Total & 39 & 49 & 2 & 100 & 100 & 100 \\
\hline
\end{tabular}


Table no. 4. Distribution of respondents by agreeing to the statement "Romanian food products are often tastier than imported ones" and the product categories where they prefer local brands

\begin{tabular}{|c|c|c|c|c|c|c|}
\hline \multirow{2}{*}{$\begin{array}{l}\text { Number of } \\
\text { product } \\
\text { categories where } \\
\text { they prefer local } \\
\text { brands }\end{array}$} & \multicolumn{3}{|c|}{ Number of respondents } & \multicolumn{3}{|c|}{$\%$ in total subgroup } \\
\hline & Agreement & $\begin{array}{c}\text { Partial } \\
\text { agreement }\end{array}$ & Disagreement & Agreement & $\begin{array}{c}\text { Partial } \\
\text { agreement }\end{array}$ & Disagreement \\
\hline $0-5$ & 13 & 19 & 2 & 24.5 & 52.8 & 22.2 \\
\hline $6-11$ & 24 & 14 & 6 & 45.3 & 38.9 & 66.7 \\
\hline $12-17$ & 13 & 3 & 1 & 24.5 & 8.3 & 11.1 \\
\hline $18-22$ & 3 & & & 5.7 & 0.0 & 0.0 \\
\hline Total & 53 & 36 & 9 & 100.0 & 100.0 & 100.0 \\
\hline
\end{tabular}

Source: own research

Table no. 5. The calculated and tabulated values for $\chi^{2}$ needed to study differences in preference for local brands and agreement to the two statements

\begin{tabular}{|c|c|c|c|c|c|}
\hline \multicolumn{2}{|c|}{ Association } & $\begin{array}{c}\text { Calculated } \\
\text { value } \\
\chi^{2}\end{array}$ & $\begin{array}{c}\text { Degree of } \\
\text { freedom }\end{array}$ & $\begin{array}{c}\text { Level of } \\
\text { significance } \\
(\%)\end{array}$ & $\begin{array}{c}\text { Tabulated } \\
\text { value } \\
\chi^{2}\end{array}$ \\
\hline $\begin{array}{c}\text { Number of } \\
\text { product } \\
\text { categories } \\
\text { where they } \\
\text { prefer local } \\
\text { brands }\end{array}$ & $\begin{array}{c}\text { Agrees with the statement "In } \\
\text { general, Romanian food } \\
\text { products are healthier than } \\
\text { imported ones' }\end{array}$ & 10,95 & 6 & 10 & 10,64 \\
\cline { 2 - 6 } & $\begin{array}{c}\text { Agrees with the statement } \\
\text { "Romanian food products are } \\
\text { often tastier than imported } \\
\text { ones" }\end{array}$ & 12,63 & 6 & 5 & 12,59 \\
\hline
\end{tabular}

Note: table results attest that the differences between the two pairs of correlated variables are significant only for the students collectivity from which the sample was extracted

Source: own research

\section{Conclusions}

Main results of research undertaken with reference to young preference to local or foreign brands (on the Romanian market) testifies that overall local brands of food products are preferred by young people in greater extent compared to foreign brands. Products that young people prefer in a greater extent Romanian brands are especially: eggs, bread and milling, milk and dairy products, fruits and vegetables, meat and meat products, over $50 \%$ of respondents preferring indigenous brands from these categories. A higher preference for foreign brands applies particularly to: coffee, chocolate, crisps and snacks, tea, confectionery, alcoholic and soft drinks, nuts and seeds, cereals (ready-to-serve), the share of those who said they prefer this category of brands not being over 50\%. Youth consider that Romanian products are tastier and healthier than foreign ones, better image enjoyed by foreign brands being generated from the promotion and packaging of products and not by their quality and Romanian products are insufficiently promoted at national level and the supply for sale is lower than the one for imported products.

These findings could form the basis of decisions of the Romanian producers of agricultural products to further promote their products and also increasing the attractiveness of packaging, particularly for the categories of products: coffee, chocolate, crisps and snacks, tea, confectionery, alcoholic beverages and soft drinks, nuts and seeds, cereals (ready-to-serve). 
I remind that the research was conducted on a sample of 100 students, selected using group sampling scheme from Bachelor students of the Faculty of Economic Sciences of the Vasile Alecsandri University of Bacau. The results are representative only for this collectivity, offering an indicative about the phenomenon investigated among young people of 18-30 years and forming hypotheses for further research, representative for larger collectivities.

\section{References}

Boier, R, Ţimiraş, L.C. (2006), Cercetarea de marketing, Iaşi, Editura Performantica; Cătoiu, I. (coord.) (2002), Cercetări de marketing, Editura Uranus, Bucureşti;

Datculescu, P. (2006), Cercetarea de marketing, Editura Brandbuilders;

Kumar V., Aaker, D.A., Day G.S. (1999), Essentials of Marketing research, John Wiley \& Sons, Inc., New York Chichester Weinheim Brisbane Singapore Toronto;

Malhotra, N.K. (2004), Marketing Research an Applied Orientation.Fourth edition, Upper Saddle River, New Jersey, Pearson Education. 